\title{
Needs Analysis of Teaching Materials for Learning Discourse Analysis
}

\author{
Yusrina $^{\text {1) }}$, Muhammad Rapi Tang ${ }^{2)}$,Syukur Saud ${ }^{3)}$ \\ ${ }^{1), 2), 3)}$ Universitas Negeri Makassar \\ email: rina7432@gmail.com ${ }^{1}$, m.rapi@unm.ac.id ${ }^{2}$, syukur.saud@unm.ac.id ${ }^{3}$
}

\begin{abstract}
Teaching materials are one of the important aspects that determine the effectiveness of learning. In learning discourse analysis, students are expected to have critical thinking skills, but this is not achieved because the teaching materials used are not in accordance with the needs of students. The purpose of this study was to analyze the needs of teaching materials to students. This research was conducted by quantitative descriptive method. Research data were collected using a questionnaire given to 30 students. The data from the questionnaires were then studied using quantitative descriptive analysis methods. Based on the results of the study obtained data that many teaching materials are not in accordance with the learning objectives that have been formulated in the lesson plan. The pattern of preparation and content of teaching materials used so far does not provide a stimulus for students to develop critical thinking skills. The results showed that students not only needed teaching materials that contained material as the object of discourse analysis studies, but also needed material on concepts and strategies in critical thinking.
\end{abstract}

Keywords: Teaching, Material, Discourse Analysis, Critical Literacy

\section{Introduction}

Learning is a process or method used to facilitate the implementation of learning activities. Good learning is learning designed by teachers with creative and innovative ideas or ideas, so that they can improve student learning outcomes and motivation. The learning carried out must be meaningful for students so that the learning materials obtained can be useful in real life (M. Khalilullah, 2012). Educators must be able to prepare learning media and teaching materials well before entering class to teach (Manullang, 2014). Good learning preparation will be the beginning of creating effective learning situations and conditions. This is done to create an effective teaching and learning process, because the success of learning is one of the important factors that determine the success of education (Faizah, 2020).

One important aspect that determines the effectiveness of learning is teaching materials (Arsanti, 2018; Gazali, 2016). Teaching materials are a source of information that will help students in learning. Therefore, teaching materials should be adapted to the learning objectives and needs of students (Sembiring, 2010). Teaching materials must be arranged systematically, uniquely, and specifically in accordance with the learning principles used by lecturers (Sungkono, 2009). In addition, the material described in the teaching materials is adaptive to the development of science and technology (Arsanti, 2018; Nuris et al., 2018). So that the contents of teaching materials are in accordance with the development of science, the references used in preparing teaching materials are the latest references.

Discourse analysis learning is one of the lessons that must be equipped with the right teaching materials. Discourse analysis learning is learning that aims to provide an understanding of concepts and strategies in analyzing discourse. In addition, in this learning, students are also expected to improve and develop their ability to think critically. So there is a mix and relevance between critical thinking skills as a tool and material for discourse analysis as study material in learning. In learning discourse analysis, lecturers must be able to provide material that contains a lot of pragmatic meaning. Searching for 
contextual meaning is one of the processes that will be carried out by students in learning discourse analysis (Silaswati, 2019). In addition, students need to be equipped with critical thinking concepts and strategies as a tool to analyze the discourse provided in teaching material.Through this learning, students will be trained to think deeply and critically about various information. Students need to be equipped with critical thinking skills, including: (1) interpreting skills, (2) analyzing skills, (3) inference skills, (4) evaluating skills, (5) explanatory skills, and (6) self-regulation skills (Facione, 2020).

Therefore, the teaching materials used in learning discourse analysis must be able to provide a stimulus to students to think actively. Good discourse analysis teaching materials are teaching materials that can make students respond back. In addition, to make it easier for students to understand the content of teaching materials, the elements of ideal teaching materials must be fulfilled. Several criteria need to be considered in preparing teaching materials, namely: 1) equipped with learning instructions; 2) contains learning competencies that must be achieved; 3) helping students to think critically; 4) accompanied by examples or illustrations; 5) according to the context and events that often occur in the community; and 6) use simple language that is easily understood by students.

However, based on the results of a study of several references and research articles, data were obtained that there were still many uses of teaching materials that were not in accordance with the learning objectives and needs of students, including in learning discourse analysis. There are teaching materials that are not equipped with learning instructions and learning competencies to be achieved. This causes students to have difficulty understanding the content of learning so that they cannot follow the teaching and learning process properly. In the case of discourse analysis learning, the teaching materials used do not motivate students to actively think deeply. This is because the material contained in the teaching materials is sometimes not in accordance with the context of events that often occur around students. Another problem that is considered different from the concept of ideal teaching materials is that there are no concepts and strategies for critical thinking. This causes confusion for students in participating in discourse analysis lessons. Good material will not be able to be analyzed properly by students when they are not equipped with critical thinking skills. In several studies, it was also found that many teaching materials used language that was difficult to understand.

The problem of teaching materials is one of the main factors that make students unable to achieve the learning objectives that have been set in the lesson plan. Students are not able to actively participate in the learning process and are unable to improve and develop their critical thinking skills. Cognitively, students are expected to be able to understand concepts and strategies in analyzing critical discourse. In the psychomotor aspect or skills, students are expected to have critical thinking skills. These thinking skills are not only used to analyze discourse in discourse analysis learning, but can be used to examine various conditions and events that are happening in society. Critical thinking skills are very important because today is an era of globalization that is full of technological developments. This situation seems to make the world closer and information faster. Therefore, critical thinking skills are needed to be able to filter various information. The textual meaning of information is not always the same as its contextual meaning. Textual meaning can be done directly, but contextual meaning requires active and critical thinking skills. Based on the description of the gap between the existence of critical discourse analysis learning and the reality that occurs, it is necessary to conduct an in-depth study of theories and learning conditions to be used as the basis for developing teaching materials that are in accordance with the expected learning objectives and in accordance with the needs of students to develop critical thinking skills.

\section{Methods}

The method used in this research is descriptive quantitative analysis method. The data and data sources in this study were 30 students of the Indonesian language and literature education study program who had programmed the Indonesian language discourse analysis course. Research data were collected 
using a questionnaire. Data from the questionnaire was then analyzed using quantitative descriptive analysis method. Through this method, the researcher describes the problems and obstacles found in the teaching materials of Indonesian discourse analysis. Learning problems and barriers were analyzed using learning concepts and learning theories.

\section{Result and Discussion}

Based on the data that has been collected through a questionnaire sent to 30 students. The following is the data on the results of students' responses to the teaching materials used in learning discourse analysis.

Tabel 1. Teaching Material

\begin{tabular}{llcccc}
\hline \multicolumn{1}{c}{ Teaching Material Indicator } & $\mathbf{1}$ & $\mathbf{2}$ & $\mathbf{3}$ & $\mathbf{4}$ \\
\hline 1 & Clarity of study instructions & 4 & 15 & 6 & 5 \\
2 & Suitability of learning objectives & 9 & 8 & 4 & 4 \\
3 & Conformity of supporting information & 6 & 16 & 3 & 5 \\
4 & Exercise Equipment & 8 & 8 & 4 & 7 \\
5 & Clarity of work instructions & 6 & 14 & 5 & 5 \\
6 & The accuracy of the evaluation section & 11 & 9 & 4 & 6 \\
7 & Can be studied independently & 3 & 14 & 6 & 7 \\
8 & Integrity of teaching materials & 10 & 10 & 5 & 5 \\
9 & Novelty of teaching materials & 10 & 8 & 5 & 7 \\
10 & Adaptive to the development of science and & 8 & 10 & 6 & 6 \\
& technology & 8 & 9 & 5 & 8 \\
11 & Improve critical thinking skills & 6 & 10 & 7 & 7 \\
12 & Suitability of examples or illustrations & 7 & 11 & 4 & 8 \\
13 & Motivate students to respond & 7 & 12 & 6 & 5 \\
14 & Context fit & 5 & 11 & 8 & 6 \\
15 & Simplicity and clarity of language & 108 & 165 & 78 & 91 \\
\hline & $\quad$ Total score & $24 \%$ & $36,6 \%$ & $17,3 \%$ & 20,2 \\
\hline
\end{tabular}

Information:

Total of Respondent $=30$

Score Category:

$1=$ Very low

$2=$ Low

$3=$ tall

$4=$ very high

Formula:

$\%=\frac{\text { skor perolehan }}{\text { skor maksimal } \mathrm{x} \text { jumlah responden }} \times 100 \%$

Based on the data in table 1 which contains students' responses to the Indonesian language discourse analysis teaching materials based on the indicators of the components of teaching materials in general the percentage score 1 (very low value category) is $24 \%$, score 2 (low value category) is $36.6 \%$, score 3 (high score category) is $17.3 \%$, and score 4 (very high score category) is $20.2 \%$. Based on these data, it can be concluded that the level of student satisfaction with the quality of the teaching materials used is still dominant in the low category. Based on the results of the study, it can be seen that the Indonesian 
language discourse analysis teaching materials have weaknesses and challenges. The components of teaching materials that need improvement include: (1) clarity of learning instructions, (2) suitability of learning objectives, (3) suitability of supporting information, (4) completeness of training, (5) clarity of work instructions, (6) accuracy of the evaluation section, (7) can be studied independently, (8) the integrity of teaching materials, (9) the novelty of teaching materials, (10) adaptive to the development of science and technology, (11) improve critical thinking skills, (12) suitability of examples or illustrations, (13) motivate students to provide responses, (14) appropriateness to the context, (15) simplicity and clarity of language. Indicators of clarity of learning instructions, most of the respondents rated it low. From a theoretical perspective, learning instructions in teaching materials are very important.

Learning instructions can be a guide for students during the learning process. Indicators of suitability of learning objectives, most respondents rate very low. In a theoretical perspective, learning objectives are indicators that aim to determine what students will achieve when learning to implement learning. Learning objectives aim to determine the needs faced by students, attitudes, knowledge, and skills that have not been mastered and are important for students. Learning objectives must be in accordance with the characteristics of the learner and pay attention to the needs and concerns/interests of the learner. Indicators of suitability of supporting information, most respondents rate it low. Based on the theory, supporting information is needed in preparing teaching materials. Supporting information is a variety of additional information to complement teaching materials, so that students are increasingly assisted in mastering the knowledge they will acquire. Completeness of the exercises, most of the respondents rated the category very low and low. In a theoretical perspective, displaying practice questions, assignments, and the like allows students to respond and can be used to measure the level of mastery of learning materials. In addition, exercises and assignments also serve to mature students' abilities. Clarity of work instructions, most of the respondents rated the category low.

From a theoretical perspective, work instructions are important in teaching materials. Work instructions are provisions that must be followed in carrying out learning. Work instructions become guidelines for students in carrying out learning activities. Work instructions can direct students to learn independently. The accuracy of the evaluation section, most of the respondents rated the category very low. Based on the theory, the indicator of the accuracy of the evaluation section is very important. Remember, evaluation is part of the assessment process. Because in the evaluation element there are a number of questions addressed to students to measure how far the mastery of competencies they have mastered after participating in the learning process. With the element of evaluation we can find out the effectiveness of the materials used. If the placement of the evaluation section is not considered, it will have an impact on ineffective assessment results. Can be studied independently, most of the respondents rated the low category. Based on the theory, one of the characteristics of teaching materials is that they can be studied independently. Currently the learning process is student-centered. Therefore, it is very important to provide teaching materials that can make students learn independently without having to always be guided by the teacher. Integrity of teaching materials, most of the respondents rated the category very low and low. Based on the theory, what is meant by the integrity of teaching materials is that the breadth and depth of the content of teaching materials are closely related to the depth of content or material, as well as the integrity of concepts based on science. In this case how much or broad a topic that we will present to students? How deep is the topic covered? Many considerations need to be made to answer this question. Among other things and the most important is the learning objectives. Each teaching material must have a purpose that will be conveyed to students.

Based on the learning objectives we can determine how broad, deep and complete the topic we present to students. The novelty of teaching materials, most of the respondents rated the category very low. Based on the theory, the novelty of teaching materials is an important thing as a benchmark for the effectiveness of teaching materials. The analogy, if we present new things to students, it will motivate students to learn the information presented. Adaptive to the development of science and technology, most of the respondents rated the category low. Based on the theory, teaching materials should have a high 
adaptability to the development of science and technology. It is said to be adaptive if the teaching materials can adapt to the development of science and technology, and are flexible or flexible to use in various hardware (hardware). Improving critical thinking skills, most of the respondents rated the category low. Based on the theory, critical thinking is a skill that must be mastered by students. Teaching materials are expected to be able to develop students' critical thinking skills. Students need to be equipped with critical thinking concepts and strategies as a tool to analyze the discourse given in teaching materials. Through this learning, students will be trained to think deeply and critically about various information.

The suitability of the example or illustration, most respondents rate it low. In a theoretical perspective, the suitability of examples and illustrations is needed. The suitability of examples and illustrations serves to support the clarity of the presentation of learning materials. Motivating students to respond, most of the respondents rated the category low. Based on the theory, teaching materials should motivate students to respond. One of the objectives of teaching materials is to provide a stimulus to students to respond. Student-centered learning means that students must be active in learning activities. Therefore, good teaching materials must motivate students to be active in learning. According to the context, most of the respondents rated the category low. Based on the theory, teaching materials presented to students must be in accordance with the context of the learning objectives or competencies that must be mastered contained in the curriculum and syllabus. If the teaching materials are not in accordance with the context of the learning objectives, it will hinder students from mastering the knowledge to be achieved. Simplicity and clarity of language, most respondents rate the category low. Based on theory, teaching materials should use correct and standard language, sentences used are in accordance with the level of maturity and development of students, terms or vocabulary and symbols can facilitate student understanding, and use transliteration standardized. Therefore, to solve problems in learning discourse analysis, the teacher must do various things. First, compiling learning materials according to the curriculum. Second, in formulating learning objectives the teacher must adjust to the abilities of students. Third, the level of readability, both in terms of language difficulty and substance, must be in accordance with the level of student ability. Fourth, the systematic preparation of teaching materials must be clear, coherent, complete and easy to understand. In addition, to improve students' critical thinking skills in learning discourse analysis, teachers also need to develop student skills such as: (1) interpreting skills, (2) analyzing skills, (3) inference skills, (4) evaluating skills, (5) skills explaining, and (6) self-regulation skills.

\section{Conclusion}

Based on the literature review and research results, it can be concluded that Indonesian language discourse analysis teaching materials still have many problems and obstacles. The problem lies in various components. The results of the analysis of the need for teaching materials in this study also inform about the problems faced by lecturers and students in terms of teaching materials so far. The teaching instructions used still need to be explained clearly and in accordance with the learning objectives. The teaching materials used so far still need to be supported by the latest references in order to keep up with the development of science. The exercises used must be aligned with the material and the learning context. The teaching materials used so far are still difficult for students to understand and do not motivate students to think critically. Therefore, it can be concluded that teaching materials are needed that can facilitate students to improve critical thinking skills as an alternative solution to solve problems that are found and meet the needs of using teaching materials in discourse analysis learning.

\section{Acknowledgments}

I thank God for all the blessings that have been given by Allah swt. I would like to express my gratitude to my dissertation supervisors who always provide guidance and motivation so that this research 
article can be completed properly. I also thank my family and friends who have always provided advice and contributed ideas during my research., I do not forget to express my appreciation to the respondents who have been willing to take the time to share information through the questionnaire that I have provided for the sake of this research. And finally, I would also like to thank all the organizers of the "1st International Virtual Conference on Language Pedagogy" who have provided a platform for me to convey the results of this research.

\section{References}

Arsanti, M. (2018). Pengembangan bahan ajar mata kuliah penulisan kreatif bermuatan nilai-nilai pendidikan karakter religius bagi mahasiswa prodi PBSI, FKIP, Unissula. KREDO: Jurnal Ilmiah Bahasa Dan Sastra, 1(2), 71-90.

Facione, P. A. (2020). Critical thinking: what it is and why it counts 2020 update. In e-conversion Proposal for a Cluster of Excellence: Vol. XXVIII (Issue 1).

Faizah, S. N. (2020). Hakikat belajar dan pembelajaran. At-Thullab: Jurnal Pendidikan Guru Madrasah Ibtidaiyah, 1(2), 175.

Gazali, R. Y. (2016). Pengembangan bahan ajar matematika untuk siswa SMP berdasarkan teori belajar ausubel. Pythagoras: Jurnal Pendidikan Matematika, 11(2).

M. Khalilullah, S. A. M. (2012). Permainan teka-teki silang sebagai media dalam pembelajaran bahasa Arab (Mufradat). Jurnal Pemikiran Islam, 37(1), 15-26.

Manullang, M. (2014). Manajemen pembelajaran matematika. Jurnal Pendidikan Dan Pembelajaran Universitas Negeri Malang, 21(2), 208-214.

Nuris, D. M., Nagari, P. M., \& Nuraini, U. (2018). Pelatihan pembuatan bahan ajar dan media pembelajaran berbasis TIK bagi guru akutansi. E-Conversion - Proposal for a Cluster of Excellence, 4(1), 29-50.

Sembiring, R. K. (2010). Pendidikan Matematika Realistik Indonesia (PMRI): Perkembangan dan tantangannya. Journal on Mathematics Education, 1(1), 11-16.

Silaswati, D. (2019). Analisis wacana kritis dalam pengkajian wacana. Metamorfosis: Jurnal Bahasa, Sastra Indonesia dan Pengajarannya, 12(1), 1-10.

Sungkono, S. (2009). Pengembangan dan pemanfaatan bahan ajar Modul dalam proses pembelajaran. Majalah Ilmiah Pembelajaran, 5(1). 